\section{Entre la escalera ascendente y la espiral recurrente Los procesos de adquisición de conocimiento en tiempos de textos e hipertextos ${ }^{(1)}$}

(1) Este artículo se elaboró sobre la base de una clase desarrollada en el Seminario «Psicología \& Educación» dictado por el autor en el marco del Programa del Doctorado en Educación de la Facultad de Humanidades

y Artes se la UNR en julio

2012 y sobre una Conferencia presentada en la Jornada «La Educación Superior en la Provincia de Santa

Fe» Instituto de Educación Superior «Olga Cossettini» en

Rosario, en mayo de 2013.

(2) Facultad Psicología, Universidad Nacional de Rosario.

E-mail: felixtemporetti@ yahoo.com.a
Félix Temporetti ${ }^{(2)}$

Palabras clave. educación · conocimiento narrativas · alfabetización

Resumen. Se analizan y reflexiona, adoptando una perspectiva histórica crítica, los cambios, convivencia y entrecruzamiento de dos modelos para leer, pensar, narrar, adquirir y comunicar conocimientos que es posible reconocer en los tiempos actuales y que constituye un asunto central en la educación formal. La escalera ascendente refiere al modelo construido sobre los principios de la llustración, sostenido en la escritura y narrativa lineal analógica siendo su soporte material el texto impreso. La espiral recurrente alude a un modelo de conocimiento que emerge en el siglo XIX y se afianza en el siglo XX sobre las ideas de los románticos, dialécticos, pragmáticos, constructivistas y hermenéuticos adquiriendo un protagonismo relevante en las últimas décadas con la emergencia concreta de la escritura y narrativa hipertextual multimedial digital y el texto informatizado. Se sostiene que en la actualidad conviven procesos y productos de mixturas entre textos e hipertextos, entre narrativas lineales y multimediales. Se proporcionan algunas ideas para repensar la tarea de educar y enseñar, en particular los procesos de alfabetización, en las primeras décadas del siglo XXI. 
Keywords. education - knowledge

narratives $\cdot$ literacy processes

Abstract. We analyze and reflect, adopting a critical historical perspective, changes, coexistence and interweaving of two models for reading, thinking, storytelling, acquiring and sharing knowledge that can be recognized in modern times and is a key issue in formal education. The ascending ladder refers to the model built on the principles of the Enlightenment, sustained by writing and linear narrative ana$\log$, being the medium used printed text. The recurrent spiral refers to a model of knowledge that emerged in the nineteenth century and is secured in the twentieth century with romantic, dialectical, pragmatic, constructivist and hermeneutic ideas acquiring an important role in recent decades with the emergence of hipertextual narrative and digital multimedia hypertext and computerized text. It is argued that currently coexist processes and products of mixtures between text and hypertext, between multimedia and linear narrative. Some ideas to rethink the task of educating and teaching, especially literacy processes in the early decades of the twenty-first century are proposed.

\section{Planteo del problema}

La expresión metafórica utilizada para titular este ensayo: Entre la escalera ascendente y la espiral recurrente pretende sintetizar algunas de las ideas y argumentos principales que aquí se exponen. Se reflexiona sobre las transformaciones actuales que acontecen en el campo del conocimiento, su transmisión y comunicación, asunto central en las instituciones educativas desde que comenzó el armado e institucionalización de la denominada educación formal. El tema en cuestión, apreciado en una perspectiva histórica crítica, pone la mira en la secuencia de los cambios que se han venido produciendo desde la Modernidad Ilegando a la convivencia y entrecruzamiento de dos modelos para leer, pensar, narrar, adquirir y comunicar que es posible reconocer en los tiempos actuales. La escalera ascendente refiere al modelo de conocimiento construido sobre los principios de la llustración, sostenido en la escritura y narrativa lineal analógica siendo su soporte material el libro o texto impreso. La espiral recurrente alude a un modelo de conocimiento que 